http://ejournal.uhn.ac.id/index.php/opinion

\title{
TANGGUNG JAWAB PERUSAHAAN ALIH DAYA TERHADAP PEKERJA OUTSOURCHING YANG TERKENA PEMUTUSAN HUBUNGAN KERJA DIMASA PANDEMI COVID-19 (STUDI DOKUMEN PERJANJIAN PENYEDIA JASA DI PT NTU)
}

\author{
Intan Mayasari Hutabarat ${ }^{1}$, Martono Anggusti ${ }^{2}$, Christina N.M Tobing ${ }^{3}$ \\ ${ }^{1,3}$ Program Studi Ilmu Hukum \\ 2Program Studi Magister Hukum \\ Universitas HKBP Nommensen, Medan-Sumatera Utara-Indonesia \\ e-mail: intansarihutabarat@gmail.com
}

\begin{abstract}
The Covid-19 pandemic has a very big impact in the industrial world, many companies have terminated employment (PHK) for workers, both PKWTT and PKWT. In the Manpower Act No. 13 of 2003 and the Job Creation Act No. 11 of 2020 concerning labor and termination of employment. Regarding termination of employment, termination of employment to outsourced workers, the author discusses 2 (two) problem formulations, namely: First: How is the responsibility of outsourcing companies to outsourcing workers / laborers who were terminated during the Covid-19 pandemic; Second, what is the comparison of the forms of legal protection for outsourcing workers / laborers who have experienced termination of employment according to Law no. 13 of 2003 concerning Manpower and Law no. 11 of 2020 About Job Creation. The research method used in this thesis is the Normative-Empirical method. The conclusion of this decision is First, that the outsourcing company is still in charge of the implementation of termination of employment, this can be seen in the PT SIS PKWT; Second, in terms of comparison between UUK No. 13 of 2003 with UUCK No.11 of 2020 not much has changed, only in UUKC regarding labor Outsourcing is more discussed.
\end{abstract}

Keywords: Responsibility, Outsourcing Labor, Layoffs

\begin{abstract}
Abstrak
Pandemi Covid-19 sungguh sangat berdampak besar dalam dunia perindustrian, banyak perusahaan yang melakukan pemutusan hubungan kerja (PHK) terhadap tenaga kerjanya baik PKWTT maupun PKWT. Didalam Undang-Undang Ketenagakerjaan No. 13 Tahun 2003 dan Undang-Undang Cipta Kerja No. 11 Tahun 2020 telah diatur mengenai tenaga kerja dan pemutusan hubungan kerja. Terkait pemutusan hubungan kerja khususnya pemutusan hubungan kerja terhadap tenaga kerja outsourcing, penulis membahas mengenai 2 (dua) rumusan masalah yaitu Pertama: Bagaimana Tanggung Jawab Perusahaan alih daya terhadap pekerja/buruh outsourcing yang diputus hubungan kerjanya di masa pandemi covid-19; Kedua, Bagaimana perbandingan bentuk perlindungan hukum terhadap pekerja/buruh outsourcing yang mengalami pemutusan hubungan kerja menurut UU No. 13 Tahun 2003 Tentang Ketenagakerjaan dan UU No. 11 tahun 2020 Tentang Cipta Kerja. Metode penelelitian yang digunakan dalam penulisan Tesis ini adalah metode Normatif-Empiris. Kesimpulan dalam penulisan ini adalah Pertama, bahwa perusahaan alih daya masih kurang dalam bertanggung jawab dalam hal terjadinya pemutusan hubungan kerja, hal ini dapat dilihat dalam PKWT PT SIS; Kedua, dalam hal perbandingan antara UUK No. 13 Tahun 2003 dengan UUCK No.11 Tahun 2020 tidak banyak yang berubah hanya di dalam UUKC mengenai tenaga kerja Outsourcing lebih di seirus dibahas.

Kata kunci: Tanggung Jawab, Tenaga Kerja Outsourcing, PHK
\end{abstract}


Nommensen Journal of Legal Opinion (NJLO)

Jurnal Magister Hukum Program Pascasarjana Universitas HKBP Nommensen

Volume 02 Nomor o1 Januari 2021 Halaman. 55-79 e-ISSN: 2723-164X p-ISSN: 2722-9858

http://ejournal.uhn.ac.id/index.php/opinion

\section{A. Pendahuluan}

Masalah ketenagakerjaan sering sekali menjadi topik pembicaraan hangat dan aktual di tengah masyarakat, mulai dari masalah upah, jam kerja, waktu lembur, jaminan keselamatan dan kesehatan kerja, jaminan hari tua, hingga masalah pemutusan hubungan kerja (PHK), termasuk masalah outsourcing atau alih daya dan ditambah saat ini adalah jaminan kehilangan pekerjaan (JKP). Hal ini tentunya menjadi perhatian dari seluruh stakeholder untuk dapat memahami ketentuan peraturan perundang-undangan yang berlaku dalam hubungan kerja dan setelah hubungan kerja berakhir, sehingga hubungan yang harmonis antara pekerja dan pengusaha tetap berjalan dengan baik.

Awal tahun 2020, dunia dihebohkan dengan adanya globalisasi, revolusi industri dan virus Corona atau COVID-19 yang berdampak pada perekonomian dunia termasuk perekonomian di Indonesia, dunia perindustrian mengalami dampak serius. Tidak sedikit perusahaan yang mengalami gulung tikar atau bangkrut, ribuan bahkan ratusan ribu pekerja harus mengalami PHK, baik tenaga kerja tetap maupun tenaga kerja outsoucing ${ }^{l}$, ada Dalam data Kementerian Ketenagakerjaan, sebanyak 2,8 juta kasus pemutusan hubungan kerja (PHK) telah dilaporkan selama masa pandemi ini $^{2}$ dan tercatat sekitar 20.000 pekerja/buruh outsourcing terkena PHK selama masa pandemi covid-1933, tentunya ini menjadi tantangan besar bagi negara Indonesia untuk keluar dari masalah ini.

Penelitian ini akan membahas mengenai pekerja/buruh outsourcing atau yang dalam dunia kerja sering disebut pekerja/buruh alih daya, yakni pekerja yang dialihkan untuk bekerja ke perusahaan lain. Dalam undang-undang, kedua istilah tersebut tidak dijelaskan secara langsung, namun secara implisit pengaturannya terlihat dalam Pasal $64^{4}$, Pasal 65 , Pasal 66 Undang-Undang Nomor 13 Tahun 2003 tentang Ketenagakerjaan (UUK). Pasal 64, menyebutkan bahwa mengenai hak perusahaan dalam menetapkan pemberian pekerjaan kepada pekerja.

Undang-Undang No. 11 Tahun 2020 tentang Cipta Kerja (UU Cipta Kerja) telah menghapuskan ketentuan Pasal 64 dan Pasal 65 UUK serta merubah ketentuan Pasal 66 UUK, sehingga akan berdampak pada praktik sistim outsourcing di Indonesia. Penghapusan Pasal 64 dan Pasal 65 oleh UU Cipta Kerja, berarti sistim outsourcing yakni penyerahan sebagian pekerjaan tidak lagi dikenal melalui perjanjian pemborongan, tetapi hanya dibenarkan melalui perjanjian penyedia jasa pekerja/buruh alih daya sebagaimana diatur Pasal 66 UUK Jo. Pasal 81 angka 20 UU Cipta Kerja5.

\footnotetext{
${ }^{1}$ Menurut Husni Outsourcing adalah pemanfaatan tenaga kerja untuk memproduksi atau melaksanakan suatu pekerjaan oleh suatu perusahaan, melalui perusahaan penyedia/pengerah tenaga kerja, eprints.uny.ac.id/23966/2/Bab II.pdf, diakses tanggal o8 Maret 2021.

${ }^{2}$ https://www.legalku.com/pemutusan-hubungan-kerja-phk-di-masa-pandemi-bagaimana aturannya/ diakses pada tanggal 17 Maret 2021.

${ }^{3}$ https://www.cnbcindonesia.com/market/20200625141748-19-167988/abadi-20-ribu-pekerja-alih-daya-terkena-phkakibat-pandemi, diakses tanggal 28 Januari 2021.

${ }^{4}$ Pasal 64 Undang-Undang Nomor 13 Tahun 2003 Tentang Ketenagakerjaan, menyebutkan: "Perusahaan dapat menyerahkan sebagian pelaksanaan pekerja kepada perusahaan lainnyya melalui perjanjian pemborongan pekerjaan atau penyediaan jasa pekerja/buruh yang dibuat secara tertulis".

${ }^{5}$ Pasal 81 angka 20 Undang-Undang Nomor 11 Tahun 2020 Tentang Cipta Kerja, menyebutkan: "Ketentuan Pasal 66 diubah sehingga berbunyi sebagai berikut: (1) Hubungan kerja antara perusahaan alih daya dengann oekerja/buruh yang dipekerjakannya didasarkan pada perjanjian kerja yang dibuat secara tertulis, baik perjanjian kerja tertentu maupun perjanjian kerja tidak tertentu. (2) Perlindungan pekerja/buruh, upah dan kesejahteraan, syarat-syarat kerja, serta perselisihan yang timbul dilaksanakan sekurang-kurangnya sesuai dengan ketetuan peraturan perundang-undangan dan menjadi tanggung jawab perusahaan alih daya. (3) Dalam hal perusahaan alih daya
} 
Dalam sistim outsourcing terdapat 2 (dua) jenis perjanjian, yakni Perjanjian Penyedia Jasa Pekerja dan Perjanjian Kerja. Perjanjian Penyedia Jasa Pekerja adalah perjanjian antara perusahaan pemberi kerja dengan perusahaan penyedia jasa pekerja, dimana perusahaan penyedia jasa pekerja (perusahaan outsourcing) akan menempatkan pekerja ke perusahaan pemberi kerja untuk pekerjaan tertentu dan dalam jangka waktu tertentu dengan memperoleh imbalan berupa $f e e^{6}$. Sedangkan Perjanjian Kerja adalah perjanjian antara perusahaan outsourcing dengan pekerja yang bentuknya dapat merupakan perjanjian kerja waktu tidak tertentu (PKWTT) dan perjanjian kerja waktu tertentu (PKWT) ${ }^{7}$. Apabila perjanjian penyedia jasa pekerja berakhir, maka berakhir pula pekerjaan pekerja di perusahaan pemberi kerja. Untuk pekerja alih daya yang diikat dengan PKWTT, maka perlindungan upah tetap ada, berbeda dengan pekerja yang diikat dengan PKWT, maka tidak ada perlindungan kelangsungan pekerjaan apalagi upah.

Sistem kerja kontrak outsourcing yang membuka peluang kerja di semua jenis pekerjaan dan mengutamakan angkatan kerja muda akan menyebabkan kesempatan kerja bagi buruh usia 30 tahun makin menyempit. Bila peluang kerja di sektor formal bagi angkatan kerja tua makin menyempit, maka akan terjadi ledakan sektor informal yang selama ini sudah mendominasi struktur angkatan kerja Indonesia. Di samping itu, ledakan jumlah pekerja/buruh di sektor informal tentu akan berdampak pada ketidakpastian kelangsungan pekerjaan pekerja/buruh yang akhirnya akan berdampak pula terhadap kelangsungan nafkah keluarganya.

Hubungan baik antara para pekerja/buruh outsourcing dengan perusahaan akan menimbulkan hubungan kerja yang lebih berkualitas, dimana para pekerja/ buruh merasa lebih dihargai karena dilindungi hak-haknya, sehingga pekerja/buruh akan memberikan kinerja yang maksimal. Untuk itulah diperlukan peran pemerintah sebagai regulator dan pengawas bidang ketenagakerjaan, dapat bersifat netral dan dapat menjamin pelaksanaan hak dan kewajiban para pihak dalam hubungan kerja, sebagaimana amanat konstitusi Pasal 27 ayat (2) UUD NRI Tahun 1945, "Tiap-tiap warga negara berhak atas pekerjaan dan penghidupan yang layak bagi kemanusiaan". Kemudian diatur lebih lanjut dalam Pasal 6 UU Ketenagakerjaan yang isinya "setiap pekerja/buruh berhak memperoleh perlakuan yang sama tanpa diskriminasi dari pengusaha”.

Untuk melakukan analisa yang lebih komprehensif dan dapat dipertanggungjawabkan secara metodologis tentang permasalahan ini, penulis memilih judul "Tanggung Jawab Perusahaan Alih Daya Terhadap Pekerja Outsourcing Yang Terkena Pemutusan Hubungan Kerja di Masa Pandemi Covid-19 (Studi Dokumen Perjanjian Penyedia Jasa di PT NTU).” Dari judul diatas, maka rumusan masalah yang akan dikaji dalam penulisan ini adalah : Pertama,

Bagaimana Tanggung Jawab Perusahaan alih daya terhadap pekerja/buruh outsourcing

mempekerjakan pekerja/buruh berdasarkan perjanjian kerja waktu tertentu sebagaimana yang dimaksud pada ayat (1), perjanjian kerja tersebut harus mengsyaratkan pengalihan perlindungan hak-hak bagi pekerja/buruh apabila terjadi pergantian perusahaan alih daya dn sepanjang objek pekerjannya tetap ada. (4) Perusahaan alih daya sebagaimana dimaksud pada ayat (1) berbentuk badan hukum dan wajib memenuhi Perizinan Berusaha yang diterbitkan oleh Pemerintah Pusat. (5) Perizinan Berusaha sebagaimana dimaksud pada ayat (4) harus memenuhi norma, standar prosedur, dan kriteria yang ditetapkan oleh Pemerintah Pusat. (6) Ketentuan lebih lanjut mengenai perlindungan pekerja/buruh sebagaimana dimaksud pada ayat (2) dan Perizinan Berusaha sebagaimana dimaksud pada ayat (4) diatur dalam Peraturan Pemerintah.

${ }^{6}$ Fee menurut kamus Inggris-Indonesia, arti kata "fee" bahasa Inggris dalam bahasa Indonesia. Kb. Biaya, ongkos, bayaran.

${ }^{7}$ Lihat Ketentuan Pasal 66 ayat (1) dan ayat (2) UU No. 13 Tahun 2003 tentang Ketenagakerjaan. 
Jurnal Magister Hukum Program Pascasarjana Universitas HKBP Nommensen

Volume o2 Nomor o1 Januari 2021 Halaman. 55-79 e-ISSN: 2723-164X p-ISSN: 2722-9858

http://ejournal.uhn.ac.id/index.php/opinion

yang diputus hubungan kerjanya di masa pandemi covid-19? ; Kedua, Bagaimana perbandingan bentuk perlindungan hukum terhadap pekerja/buruh outsourcing yang mengalami pemutusan hubungan kerja menurut UU No. 13 Tahun 2003 Tentang Ketenagakerjaan dan UU No. 11 tahun 2020 Tentang Cipta Kerja?

\section{B. Metode Penelitian}

Penelitian ini adalah penelitian hukum normatif empiris, yang pada dasarnya merupakan penggabungan antara pendekatan hukum normatif dengan adanya penambahan berbagai unsur empiris. Penelitian hukum normatif empiris mengenai implementasi ketentuan hukum normatif (undang-undang) dalam aksinya pada setiap peristiwa hukum tertentu yang terjadi dalam suatu masyarakat. Dalam penelitian ini juga merupakan kategori Non-Judicial Case Study, yakni pendekatan studi kasus yang tanpa konflik sehingga tidak ada campur tangan dengan pengadilan, yakni praktek pekerja outsourcingyang dipekerjakan di PT Nasional Tetap Unggulan.

Penelitian Hukum Normatif-Empiris mengutamakan Data Sekunder, baik berupa Bahan Hukum Primer, Bahan Hukum Sekunder dan Bahan Hukum Tersier. Data Sekunder tersebut kemudian dikuatkan atau didukung dengan Data Primer, berupa wawancara dengan narasumber terkait dengan topik penelitian.

\section{Pembahasan}

\section{Legalitas Perjanjian Kerja Penyedia Jasa Pekerja antara PT. SIS dengan PT NTU.}

Hasil penelitian ditemukan bahwa perikatan antara PT SIS dengan PT NTU adalah berupa Surat Perintah Tugas (terlampir). Setelah penulis teliti, maka di dalam Surat Perintah Tugastersebut ada ketentuan-ketentuan yang disetujui oleh kedua belah pihak. Isi surat perintah kerja tersebut adalah sebagai berikut.

1. Pihak penerima tugas menyediakan para pekerjanya berikut uniform dan kelengkapan cleaning support lainnya seperti mesin, cleaning chemical, peralatan dan segala sesuatu yang berhubungan dengan pelaksanaan pekerjaan.

2. Pekerjaan dilakukan dengan spesifikasi dan syarat-syarat dari pemberi tugas.

3. Pihak penerima tugas bertanggug jawab penuh atas pekerjaannya, perlatan

4. kerja, juga bertanggung jawab penuh atas kerapian pekerjaan dan kebersihan lokasi selama dan sesudah pelaksanaan pekerjaan.

5. Penggunaan tenaga kerja sebanyak 2 (dua) orang cleaner nilai kontrak perbulan sebesar Rp. 7.776.00o,- (tujuh juta tujuh ratus tujuh puluh enam ribu rupiah) dan harga sudah termasuk pajak (PPn 10\% \& PPh 2\%).

6. Pembayaran invoice akan dibayarkan dalam waktu 2 minggu setelah invoice diterima.

7. Hari kerja : Senin s/d Sabtu

Jam kerja $\quad$ : o8.00-16.0o \& 13.00-21.00

Dari isi perjanjian tersebut dapat dilihat bahwa didalam surat perintah kerja antara PT SIS dengan PT NTU adanya ketentuan-ketentuan yang disepakati kedua belah pihak, adanya kecakapan dalam melakukan perjanjian, adanya objek yang diperjanjikan, dan adanya sebab yang halal. sehingga telah memenuhi syarat-syarat suatu perjanjian sebagaimana ketentuan Pasal 1320 KUHPerdata.

Hasil penelitian penulis terhadap dokumen ini, maka hubungan hukum yang terdapat dalam perjanjian ini bukanlah didasarkan perjanjian kerja yang termasuk lingkup UUK. Hal ini disebabkan tidak terdapat hubungan kerja sebagaimana ketentuan Pasal 1 angka 15 UU 
Ketenagakerjaan yakni antara pengusaha dengan pekerja yang memuat unsur-unsur pekerjaan, upah dan perintah.Kedudukan PT NTU selaku pihak pemberi kerja dengan PT SIS selaku pihak penerima pekerjaan adalah seimbang, sehingga masuk lingkup hukum perdata umum.

Meskipunperjanjian ini berada di lingkungan hukum perdata umum, akan tetapi mengenai alih daya telah diatur secara khusus oleh hukum ketenagakerjaan, yakni ketentuan Pasal 66 UUKetenagakerjaan (sebelum dana sesudah UU Cipta Kerja)juncto Permenakertrans RI No. 19 Tahun 2012 Tentang Syarat-Syarat Penyerahan Sebagian Pelaksanaan Pekerjaan Kepada Perusahaan Lain diubah dengan Permenakertrans No. 27 Tahun 2014 (selanjutnya disebut Permenakertrans No. 19 Tahun 2012) jo. PP No. 35 Tahun 2021. Hal-hal yang diatur adalah mengenai syarat-syarat penyerahan pekerjaan melalui penyediaan jasa pekerja seperti bentuk perjanjian, bentuk perusahaan dan perijinan perusahaan outsourcing dan perusahaan pemberi pekerjaan, jenis-jenis pekerjaan yang boleh diberikan kepada perusahaan alih daya(outsourcing).

Subjek yang terikat dalam dalam PPJP ini, adalah :

1) Pihak pemberi pekerjaan yaitu PT. NTU.

PT NTU berdiri sejak tahun 2019, bergerak di bidang usaha Pendidikan Lainnya Swasta dengan Nomor Induk Berusaha (NIB) : 9120103550565 , bertempat tinggal di Jl. Perintis Kemerdekaan No. 3A Kel.Perintis, Kec. Medan Timur, Kota Medan, dengan Nomor Pokok Wajib Pajak: 313143133111000.

2) Pihak penerima pekerjaan yaitu PT. SIS (selanjutnya disebut Perusahaan Outsourcing), dalam praktik sering disebut vendor atau mitra.

Objek perjanjian adalah sebagian pekerjaan PT NTU yang diserahkan kepada PT SIS (Perusahaan Outsourcing),dan Perusahaan Outsourcing menyediakan tenaga kerja untuk melakukan sebagian pekerjaan tersebut di Perusahaan PT NTU. Dari segi objek alih daya, ada prinsip yang harus dipahami bahwa yang boleh diserahkan kepada Perusahaan Outsourcing adalah pekerjaannya yang dalam hal ini adalah cleaning service, bukan pekerjanya.Karena pekerja adalah subjek hukum, bukan objek hukum.

Berikut akan dianalisis apakah syarat-syarat perjanjian berupa Surat Perintah Kerja antara PT. NTU dengan dengan PT. SIS telah memenuhi ketentuan Pasal 66 UUK juncto pasal 17 s.d 32 Permenakertrans RI No. 19 Tahun 2012 diubah dengan Permenakertrans No. 27 Tahun 2014, sebagaimana telah diuraikan pada Bab Tinjauan Pustaka, yaitu :

a. Syarat Perusahaan Outsourcing.

Setelah meneliti isi dokumen Surat Perintah Kerja dan PKWT, maka syarat Perusahaan Outsourcing telah tepenuhi, yakni :

PT SIS Keduanya, pemberi pekerjaan dan penerima pekerjaan adalah berbentuk badan hukum PT. PT SISDidirikan berdasarkan Akta Notaris Johny Dwikora Aron, SH, dengan tanggalAkta 23 November 2009, terdaftar di Jakarta Utara Indonesia. Itu diterbitkan dalam Berita Negara pada Tahun 2012 dengan BN 28 TBN 382 /L. Alamat perusahaan yang terdaftar: JL.Prof. Dr. Latumenten Raya No. 16, Jakarta Barat. ${ }^{8}$ Dengan Nomor Pokok Wajib Pajak 02 691.431.7-038.ooo.

b. Jenis Pekerjaan.

Hasil penelitian terhadap isi perjanjian Penyedia Jasa (Alih Daya), maka pekerjaan yang diserahkan adalah cleaning service, dengan demikian telah memenuhi syarat ketentuan tentang jenis pekerjaan yang boleh diserahkan kepada Perusahaan alih daya, sebab bukan merupakan pekerjaan pokok tetapi, kegiatan penunjang PT NTU.

\footnotetext{
${ }^{8}$ https://id-check.net/sinergi-integra-services/499594.html. Diakses pada tanggal 22 Maret 2021. 
Jurnal Magister Hukum Program Pascasarjana Universitas HKBP Nommensen

Volume o2 Nomor o1 Januari 2021 Halaman. 55-79 e-ISSN: 2723-164X p-ISSN: 2722-9858

http://ejournal.uhn.ac.id/index.php/opinion

c. Bentuk Perjanjian Penyedia Jasa Pekerja harus tertulis, sekurang-kurangnya memuat :

1) Jenis pekerjaan yang akan dilakukan oleh pekerja/buruh dari perusahaan penyedia jasa pekerja/buruh;

2) Penegasan bahwa perusahaan penyedia jasa pekerja/buruh bersedia menerima pekerja/buruh dari perusahaan penyedia jasa pekerja/buruh sebelumnya untuk jenis pekerjaan yang terus menerus ada di perusahaan pemberi pekerjaan dalam hal terjadi pergantian perusahaan penyedia jasa pekerja/buruh; dan

3) Hubungan kerja antara perusahaan penyedia jasa pekerja/buruh dengan pekerja/buruh yang dipekerjakan berdasarkan PKWTT atau PKWT.

Syarat bentuk perjanjian tertulis telah terpenuhi, dan telah jelas memuat jenis pekerjaan yang akan dilakukan oleh pekerja/buruh dari perusahaan penyedia jasa. Hubungan kerja antara pekerja/buruh dengan perusahaan Outsourcing adalah PKWT. Hanya saja belum tertera syarat penegasan perusahaan outsourcing bersedia menerima pekerja/buruh dari perusahaan outsourcing sebelumnya untuk jenis pekerjaan yang terus menerus ada di perusahaan pemberi kerja dalam hal terjadi pergantian perusahaan penyedia jasa pekerja/buruh. Penegasan ini diperlukan apabila sebelumnya telah ada pekerja outsource yang dipekerjakan di perusahaan pemberi kerja oleh perusahaan outsourcing yang lain.

Apabila dianalisis, syarat ini adalah merupakan jaminan perlindungan kepada pekerja outsourcing yang diikat dengan PKWT sebagaimana amanah Putusan Mahkamah Konstitusi Nomor 27/PUU-IX/2011 tanggal 17 Januari 2012 yang menetapkan bahwa hak konstitusi pekerja outsourcing atas kelangsungan pekerjaannya harus dijamin oleh perundang-undangan. Artinya apabila pekerjaan itu masih ada dan perusahaan alih daya yang berganti, maka pekerjanya seharusnya tetap dipekerjakan oleh perusahaan alih daya yang baru di tempat yang sama, sehingga status pekerja beralih menjadi pekerja di perusahaan alih daya yang baru dan masa kerja sebelumnya tetap diperhitungkan.

Syarat lainnya adalah pendaftaran Perjanjian Penyedia Jasa Pekerja kepada instansi yang bertanggung jawab di bidang ketenagakerjaan Kabupaten/Kota tempat pekerjaan dilaksanakan, dengan melampirkan: izin operasional perusahaan penyedia jasa pekerja/buruh yang masih berlaku; dan draft perjanjian kerja antara perusahaan penyedia jasa pekerja/buruh dengan pekerja/buruh yang dipekerjakan. Syarat-syarat di atas belum tercantum dalam Perjanjian Penyedia Jasa Pekerja. Dari hasil penelitian di atas, belum semua syarat Perjanjian Penyedia Jasa Pekerja telah terpenuhi.

\section{Legalitas PKWT antara PT SIS dengan Pekerja.}

Dasar hukum Perjanjian Kerja antara Pekerja dengan Perusahaan Alih Daya adalah ketentuan Pasal 66 ayat (2) huruf b juncto Pasal 56 UUKetenagakerjaan, yakni dapat berbentuk PKWTT atau PKWT yang didasarkan pada jangka waktu atau selesainya suatu pekerjaan tertentu. Jika bentuknya PKWT, harus memenuhi ketentuan Pasal 59 UUKetenagakerjaan. Syarat lainnya adalah : harus tertulis, menggunakan bahasa Indonesia dan huruf Latin,serta tidak boleh mensyaratkan masa percobaan kerja.

Untuk jenis pekerjaan yang dapat dilakukan dengan PKWT menurut jenis dan sifat/kegiatan pekerjaannya akan selesai dalam waktu tertentu, yaitu:

a) Pekerjaan yang sekali selesai atau sementara sifatnya;

b) Pekerjaan yang diperkirakan penyelesaiannya dalam waktu yang tidak terlalu lama dan paling lama 3 (tiga) tahun; 
c) Pekerjaan yang bersifat musiman; atau

d) Pekerjaan yang berhubungan dengan produk baru, kegiatan baru, atau produk tambahan yang masih dalam percobaan atau penjajakan;

e) Pekerjaan yang jenis dan sifat atau kegiatannya bersifat tidak tetap (Revisi UU Cipta Kerja).

Selanjutnya dalam Pasal 59 ayat (2) UU Ketenagakerjaan telah ditetapkan, bahwa PKWT tidak dibenarkan untuk pekerjaan yang bersifat tetap. Pada Penjelasan pasal ini yang dimaksud dengan pekerjaan yang bersifat tetap adalah pekerjaan yang sifatnya terus menerus, tidak terputus-putus, tidak dibatasi waktu dan merupakan bagian dari suatu proses produksi dalam satu perusahaan atau pekerjaan yang bukan musiman.

Persyaratan berikutnya adalah pada Pasal 59 ayat (4) dan (5) UU Ketenagakerjaan, bahwa PKWT hanya diadakan untuk paling lama 2 (dua) tahun dan hanya boleh diperpanjang 1 (satu) kali untuk jangka waktu paling lama 1 (satu) tahun. Apabila ingin memperpanjang 7 (tujuh) hari sebelum PKWT berakhir pengusaha harus memberitahukannya kepada pekerja/buruh. Menurut Pasal 59 ayat (6) UUKetenagakerjaan PKWT dapat diperbaharui dengan syarat setelah melebihi masa tenggang 30 (tiga puluh) hari berakhirnya PKWT lama dan hanya boleh dilakukan 1 (satu) kali dan paling lama 2 (dua) tahun. Ketentuan Pasal 59 ayat (4), (5) dan ayat (6) ini telah dihapus oleh UU Cipta Kerja.

Setelah penulis telusurilebih teliti dokumen PKWT antara Pekerja dengan Perusahaan Alih Daya, maka jenis pekerjaannya adalah cleaning service, bukan merupakan bagian dari suatu proses produksi PT NTU selaku pemberi pekerjaan.Masa kerja PKWT tidak secara tegas dicantumkan berapa lama, akan tetapi disebut sampai berakhirnya proyek di tempat pekerja bekerja yakni di PT NTU, sehingga dapat dianggap memenuhi ketentuan Pasal 59 ayat (2) UUKetenagakerjaan dan Penjelasannya.

Pasal 28 Permenakertrans No. 19 Tahun 2012 sebagaimana diubah dengan Permenakertrans No. 27 Tahun 2014 menetapkan perjanjian kerja antara Perusahaan Outsourcing dengan Pekerja wajib memuat ketentuan yang menjamin terpenuhinya hak-hak pekerja sebagaimana diatur peraturan perundang-undangan. Selanjutnyaketentuan Pasal 29 ayat (1) Permenakertrans No. 19 Tahun 2012 diubah dengan Permenakertrans No. 27 Tahun 2014 menyatakan perjanjian kerja dapat berbentuk PKWT dan PKWTT. Pasal 29 ayat (2) dan ayat (3) menetapkan syarat yang wajib dimuat dalam PKWT antara Perusahaan Outsourcing dengan Pekerja/buruh, dalam hal objek kerjanya tetap ada, maka PKWT yang sekurangkurangnya harus memuat :

1) jaminan kelangsungan bekerja;

2) jaminan terpenuhinya hak-hak pekerja/buruh, meliputi : hak atas cuti apabila telah memenuhi syarat masa kerja;

3) hak-hak atas jaminan sosial;

4) hak atas THR;

5) hak istirahat paling singkat 1 (satu) hari dalam 1 (satu) minggu;

6) hak menerima ganti rugi dalam hal hubungan kerja diakhiri oleh perusahaan penyedia jasa pekerja/buruh sebelum PKWT berakhir bukan karena kesalahan pekerja;

7) hak atas penyesuaian upah yang diperhitungkan dari akumulasi masa kerja yang telah dilalui; 
Apabila PKWT tidak mencantumkan syarat sebagaimana tersebut di atas, maka PKWT menjadi PKWTT, sejak ditandatanganinya PKWT yang tidak memenuhi syarat (Pasal 30 Permenakertrans No. 19 Tahun 2012 diubah dengan Permenakertrans No. 27 Tahun 2014).

Hasil penelitian terhadap dokumen PKWT dan Surat Perintah Kerja maka dapat dianalisis persyaratan di atas sebagai berikut :

1). Jaminan kelangsungan bekerja.

Berdasarkan Putusan MK No. 27/PUU-IX/2011 juncto Pasal 32 Permenakertrans No. 19 Tahun 2012 diubah dengan Permenakertrans No. 27 Tahun 2014, maksud dari adanya jaminan kelangsungan bekerja adalah apabila terjadi pergantian perusahaan alih daya (outsourcing) di perusahaan pemberi pekerjaan, maka pekerja outsource masih tetap dapat bekerja jika pekerjaan yang dikerjakan oleh pekerjaoutsource selama ini tetap ada.Dengan demikian, perusahaan outsourcingyang baru wajib menerima pekerja outsource dengan tetap memperhitungkan masa kerja pekerja sebelumnya. Artinya, meskipun perusahaan outsourcing berganti, kelangsungan bekerja pekerja outsource tidak putus.

Setelah penulis meneliti dengan cermat isi PKWT antara Perusahaan Outsourcing dengan pekerja, tidak ada diatur tentang jaminan kelangsungan bekerja.

2). Hak cuti.

Pada Pasal VI PKWT, dicantumkan bahwa hak cuti, jam kerja, upah lembur dan potongan-potongan upah diatur tersendiri dalam Peraturan Perusahaan. Penulis tidak memperoleh dokumen Peraturan Perusahaan PT SIS. Apabila tidak diatur dalam Peraturan Perusahaan atau lebih rendah kuantitas dan kualitasnya dari UU Ketenagakerjaan, maka yang berlaku ada ketentuan UU Ketenagakerjaan sebagaimana diatur dalam Pasal 111 ayat (2) dan Penjelasannya.

Hak cuti yang diberikan oleh UUKetenagakerjaan adalah :

a. cuti tahunan sekurang-kurangnya 12 hari kerja setelah pekerja/buruh bekerja selama 12 bulan berturut-turut (Pasal 79 UUK).

b. cuti lainnya adalah karena : (Pasal 93 ayat (4) UUK)

a) pekerja sakit, menikah ( 3 hari);

b) menikahkan, mengkhitankan, membabtiskan anaknya (masing-masing 2 hari);

c) isteri melahirkan atau keguguran ( 2 hari);

d) suami/isteri, orang tua/mertua atau anak atau menantu meninggal dunia (2 hari);

e) anggota keluarga dalam satu rumah meninggal dunia (1 hari).

c. Hak atas jaminan sosial.

Hak atas jaminan BPJS Ketenagakerjaan dan BPJS Kesehatan telah dicantumkan dalam Pasal II ayat (7) PKWT, yakni jaminan BPJS Ketenagakerjaan dipotong $2 \%$, jaminan pensiun dipotong $1 \%$ dan jaminan kesehatan dipotong $1 \%$ dari upah pekerja. Akan tetapi tidak jelas keikutsertaan pekerja dalam program jaminan yang mana. Bila dilihat dari jumlah potongan upah $2 \%$ maka pekerja diikutsertakan hanya dalam program Jaminan Hari Tua, sedangkan Jaminan Kecelakaan Kerja dan Jaminan Kematiantidak jelas disebutkan.

d. Hak atas tunjangan hari raya (THR).

THR ini ada tercantum di dalam Pasal II ayat (8) PKWT, yang besarnya pro rata sesuai Peraturan perusahaan dan masa kerja pekerja. Hal ini telah sesuai dengan ketentuan UU Ketenagakerjaan yang berlaku. 
e. Hak istirahat paling singkat 1 (satu) hari dalam 1 (satu) minggu juga telah terpenuhi, sebab pekerja bekerja selama 6 (enam) hari dalam seminggu, 8 (delapan) jam sehari termasuk istirahat selama 1 (satu) jam, sebagaimana tertera pada Lampiran Surat Perintah Kerja pada Proposal Summary.Jadi persyaratan hak istirahat ini telah sesuaidengan Pasal 77 ayat (2) hurufa UUKetenagakerjaan.

f. Hak menerima ganti rugi dalam hal hubungan kerja diakhiri oleh perusahaan penyedia jasa pekerja/buruh sebelum PKWT berakhir bukan karena kesalahan pekerja tidak ada diatur dalam PKWT.

Pada Pasal III ayat (3) PKWT diatur, Pengusaha dapat memutus hubungan kerja terhadap pekerja outsource tanpa ada Surat Peringatan I, II, III dan hal-hal lainapabila ada pengurangan tenaga kerja sesuai permintaan client (dalam hal ini PT NTU) ataupun kebutuhan di area tersebut dan pekerja hanya dibayarkan gaji terakhir sesuai jumlah hari kerja. Hal ini tentu tidak sesuai ketentuan Pasal 62 UUKetenagakerjaan yang menyatakan apabila salah satu pihak mengakhiri hubungan kerja sebelum berakhirnya jangka waktu yang ditetapkan dalam PKWT, atau berakhirnya hubungan kerja bukan karena ketentuan sebagaimana dimaksud dalam Pasal 61 ayat (1), pihak yang mengakhiri hubungan kerja diwajibkan membayar ganti rugi kepada pihak lainnya sebesar upah pekerja sampai batas berakhirnya jangka waktu perjanjian kerja.

Pasal 61 ayat (1) pasca UU Cipta Kerja mengatur berakhirnya Perjanjian kerja apabila:

a. pekerja meninggal dunia;

b. berakhirnya jangka waktu perjanjian kerja;

c. selesainya suatu pekerjaan tertentu;

d. adanya putusan pengadilan dan atau putusan lembaga penyelesaian perselisihan hubungan industrial yang telah mempunyai kekuatan hukum tetap; atau

e. adanya keadaan atau kejadian tertentu yang dicantumkan dalam perjanjian kerja.

Apabila diteliti isi Pasal III ayat (3) PKWT juncto Pasal 61 ayat (1) huruf e UU Ketenagakerjaan pasca UU Cipta Kerja, maka ketentuan PKWT ini dibenarkan, yakni adanya keadaan atau kejadian tertentu yang dicantumkan dalam perjanjian kerja, akan tetapi ganti rugi tetap diberikan sesuai ketentuan Pasal 62 UU Ketenagakerjaan.

g. Hak atas penyesuaian upah yang diperhitungkan dari akumulasi masa kerja yang telah dilalui. Ketentuan pengupahan ada tercantum dalam PKWT Pasal IV :

ayat (4) : Bila tidak masuk kerja karena sakit atau izin akan dipotong gaji pokok/jumlah hari kerja $\mathrm{x}$ jumlah sakit izin dan sakit (harus disertakan surat pendukung).

ayat (5) : Bila tidak masuk kerja dikarenakan alpa (tidak ada surat pendukung) maka akan dipotong gaji pokok/jumlah hari kerja $\mathrm{x}$ jumlah alpa.

ayat (6) : Tenaga kerja baru yang masa kerjanya kurang dari 14 hari kerja maka gaji tidak akan dibayarkan.

Ketentuan ayat (4) pemotongan upah di atas tidak sesuai dengan ketentuan Pasal 93 ayat (2) huruf a UU Ketenagakerjaan, yang menetapkan bahwa upah pekerja tetap wajib dibayar bila sakit sehingga tidak dapat melakukan pekerjaannya. Berbeda halnya dengan ketentuan 
ayat (5) di atas, pekerja tidak masuk kerja karena alpa, maka pemotongan upah dapat diterima, agar pekerja tetap disiplin melaksanakan pekerjaannya. Ketentuan ayat (6) tenaga kerja baru yang masa kerjanya kurang dari 14 hari kerja tidak diberikan upah. Ketentuan PKWT ini bertentangan dengan ketentuan Pasal 93 UU Ketenagakerjaan.

Berdasarkan seluruh uraian hasil penelitian di atas, maka pada dasarnya Surat Perintah Kerja antara Perusahaan Pemberi Pekerjaan dengan Perusahaan Outsourcing, dan PKWT antara Perusahaan Outsourcing dengan Pekerja belum sepenuhnya sesuai dengan persyaratan yang ditentuan oleh ketentuan UUKetenagakerjaan dan Permenakertrans RI No. 19 Tahun 2012 diubah dengan Permenakertrans No. 27 Tahun 2014. Perjanjian antara Pemberi Pekerjaan dengan Perusahaan Outsourcing belum didaftarkan ke instansi yang bertanggung jawab di bidang ketenagakerjaan, belum mencantumkan adanya perlindungan kelangsungan kerja apabila terjadi pergantian Perusahaan Outsourcing.

\section{Hubungan hukum antara PT. SIS dengan PT NTU dan dengan Pekerja.}

Berdasarkan hasil penelitian penulis, maka berikut adalah bagan Berikut adalah skema hubungan antara perusahaan PT. NTUdengan Perusahaan OutsourcingPT SIS dan dengan Tenaga Kerja Outsoursing

\section{Bagan 4.1. Hubungan Hukum Pihak-Pihak Dalam Sistem Alih Daya}

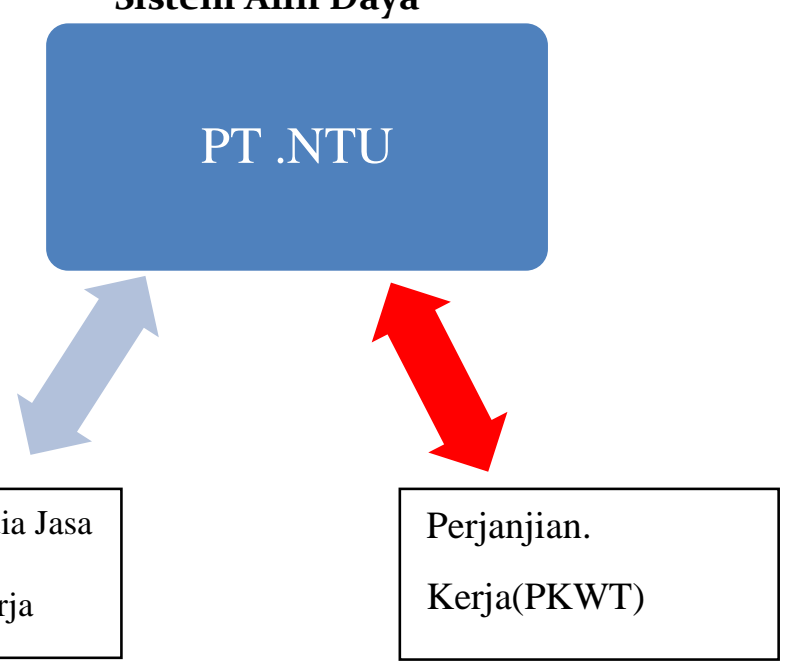

Perjanjian Penyedia Jasa

Pekerja/

Surat Perintah Kerja

\section{PERUSAHAAN}

\section{OUTSOURSING}

PT SIS

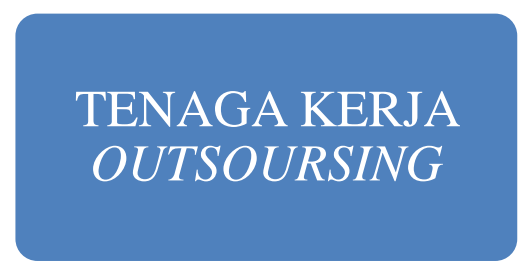

Setelah menelitiisi kedua dokumen yang penulis peroleh, maka dapat diketahui hak dan kewajiban masing-masing pihak dalam setiap perjanjian sebagaimana uraian berikut.

\section{a. Hak dan Kewajiban PT. SIS dengan PT NTU}

Dari studi dokumen Surat Perintah Kerja PT NTU kepada PT SIS, maka dapat diuraikan hak dan kewajiban para pihak sebagaimana tabel berikut : 
Nommensen Journal of Legal Opinion (NJLO)

Jurnal Magister Hukum Program Pascasarjana Universitas HKBP Nommensen

Volume 02 Nomor o1 Januari 2021 Halaman. 55-79 e-ISSN: 2723-164X p-ISSN: 2722-9858

http://ejournal.uhn.ac.id/index.php/opinion

Tabel 4.1. Hak dan Kewajiban PT SIS dan PT NTU

\begin{tabular}{|c|c|c|c|}
\hline Pasal & $\begin{array}{l}\text { Hak PT NTU/ } \\
\text { Kewajiban PT SIS }\end{array}$ & Pasal & $\begin{array}{l}\text { Hak PT SIS/ } \\
\text { Kewajiban PT NTU }\end{array}$ \\
\hline 1 & $\begin{array}{l}\text { menyediakan para pekerjanya berikut } \\
\text { uniform dan kelengkapan cleaning } \\
\text { support lainnya seperti mesin, } \\
\text { cleaning chemical, peralatan dan } \\
\text { segala sesuatu yang berhubungan } \\
\text { dengan pelaksanaan pekerjaan. }\end{array}$ & 4 & $\begin{array}{l}\text { Mempekerjakan tenaga kerja sebanyak } \\
2 \text { (dua) orang cleaner, nilai kontrak } \\
\text { perbulan sebesar Rp. } 7 \cdot 776.000,- \text { (tujuh } \\
\text { juta tujuh ratus tujuh puluh enam ribu } \\
\text { rupiah) dan harga sudah termasuk } \\
\text { pajak (PPn } 10 \% \& \text { PPh } 2 \% \text { ). }\end{array}$ \\
\hline 2 & $\begin{array}{l}\text { Pekerjaan dilakukan dengan } \\
\text { spesifikasi dan syarat-syarat dari } \\
\text { pemberi tugas (PT NTU). }\end{array}$ & 5 & $\begin{array}{l}\text { Pembayaran invoice akan dibayarkan } \\
\text { dalam waktu } 2 \text { minggu setelah invoice } \\
\text { diterima. }\end{array}$ \\
\hline 3 & $\begin{array}{l}\text { Bertanggung jawab penuh atas } \\
\text { pekerjaannya, peralatan kerja, juga } \\
\text { bertanggung jawab penuh atas } \\
\text { kerapian pekerjaan dan kebersihan } \\
\text { lokasi selama dan }\end{array}$ & & \\
\hline 6 & $\begin{array}{l}\text { sesudah pelaksanaan pekerjaan. } \\
\text { Hari kerja } \quad \text { : Senin s/d Sabtu. } \\
\text { Jam kerja: o8.oo-16.oo \& 13.00-21.oo }\end{array}$ & & \\
\hline
\end{tabular}

\section{b. Hak dan Kewajiban PT. SIS dengan Pekerja}

Berdasarkan studi dokumen PKWT antara PT SIS dengan Pekerja, dapat diuraikan hak dan kewajiban masing-masing sebagaimana tabel berikut.

Tabel 4.2. Hak dan Kewajiban PT SIS dan Pekerja

\begin{tabular}{|c|l|c|l|}
\hline Pasal & Hak PT SIS/ & Pasal & $\begin{array}{l}\text { Hak Pekerja/ } \\
\text { Kewajiban PT SIS }\end{array}$ \\
\hline $\begin{array}{c}\text { I angka } \\
(1)\end{array}$ & $\begin{array}{l}\text { Menentukan batasan fungsi, tugas dan } \\
\text { wewenang serta penetapan kerja selama } \\
\text { perjanjian kerja ini berlaku. }\end{array}$ & $\begin{array}{c}\text { II } \\
\text { angka } \\
(5)\end{array}$ & $\begin{array}{l}\text { Pekerja berhak menerima gaji } \\
\text { selama masa kontrak, sebesar Rp. } \\
2.100 . \text { ooo,-/bulan. }\end{array}$ \\
\hline $\begin{array}{c}\text { II } \\
\text { angka }\end{array}$ & $\begin{array}{l}\text { Pekerja berkewajiban mengikuti pelatihan- } \\
\text { pelatihan dan arahan kerja yang } \\
\text { dilaksanakan baik selama masa training } \\
\text { maupun selama masa kontrak. }\end{array}$ & angka & $\begin{array}{l}\text { Pekerja berhak mendapat insentif } \\
\text { masuk full selama masa kontrak, } \\
\text { sebesar Rp. 10o.ooo,-/bulan (juka } \\
\text { masuk full). }\end{array}$ \\
\hline $\begin{array}{c}\text { angka } \\
(2)\end{array}$ & $\begin{array}{l}\text { PT SIS menentukan jenis dan pekerjaan } \\
\text { bagi pekerja. }\end{array}$ & angka & $\begin{array}{l}\text { Pekerja wajib mengikuti program } \\
\text { BPJS Ketenagakerjaan (dipotong } 2 \\
\% \text { ) + Jaminan Pensiun (dipotong } \\
\text { 1\%) + BPJS Kesehatan (1\%) sesuai }\end{array}$ \\
\hline
\end{tabular}


Jurnal Magister Hukum Program Pascasarjana Universitas HKBP Nommensen

Volume o2 Nomor o1 Januari 2021 Halaman. 55-79

e-ISSN: 2723-164X

p-ISSN: 2722-9858

http://ejournal.uhn.ac.id/index.php/opinion

\begin{tabular}{|c|c|c|c|}
\hline & & & dengan peraturan pemerintah. \\
\hline $\begin{array}{c}\text { angka } \\
\text { (3) }\end{array}$ & $\begin{array}{l}\text { Pekerja wajib mematuhi Tata Tertib serta } \\
\text { ketentuan-ketentuan lain yang berlaku di } \\
\text { Perusahaan sebagaimana tercantum pada } \\
\text { lampiran dan Peraturan Perusahaan. }\end{array}$ & $\begin{array}{c}\text { angka } \\
\text { (8) }\end{array}$ & $\begin{array}{l}\text { Pekerja berhak atas Tunjangan } \\
\text { Hari Raya yang dihitung dari gaji } \\
\text { netto secara pro rata, sesuai aturan } \\
\text { perusahaan dan masa kerja yang } \\
\text { berlaku. }\end{array}$ \\
\hline $\begin{array}{l}\text { angka } \\
\text { (9) }\end{array}$ & $\begin{array}{l}\text { Pihak Kedua bersedia untuk ditempatkan di } \\
\text { Proyek mana saja sesuai dengan kebutuhan } \\
\text { perusahaan }\end{array}$ & & \\
\hline $\begin{array}{c}\text { angka } \\
\text { (10) }\end{array}$ & $\begin{array}{l}\text { Pekerja bersedia bekerja lembur bila } \\
\text { Perusahaan Outsourcing (atasan di area) } \\
\text { memandang perlu untuk kepentingan } \\
\text { Perusahaan/Proyek dan/atau atas } \\
\text { persetujuan serta permintaan dari pihak } \\
\text { customer, dimana uang lembur yang } \\
\text { dibayarkan sesuai dengan ketentuan } \\
\text { perusahaan. }\end{array}$ & & \\
\hline $\begin{array}{c}\text { angka } \\
\text { (11) }\end{array}$ & $\begin{array}{l}\text { Pekerja bersedia mengundurkan diri } \\
\text { dengan keinginan sendiri, apabila diketahui } \\
\text { dikemudian hari melakukan } \\
\text { penyelewengan dan penyimpangan yang } \\
\text { sesuai dengan ketentuan hukum pidana. }\end{array}$ & & \\
\hline $\begin{array}{c}\text { III } \\
\text { angka } \\
(1)\end{array}$ & $\begin{array}{l}\text { Masa kerja dihitung semenjak Pekerja } \\
\text { menjalankan kontrak sampai dengan waktu } \\
\text { berakhirnya Proyek ditempat Pekerja } \\
\text { menjalankan tugasnya. }\end{array}$ & & \\
\hline $\begin{array}{l}\text { III } \\
\text { angka } \\
(2)\end{array}$ & $\begin{array}{l}\text { PT SIS dapat memutuskan hubungan kerja, } \\
\text { baik pada masa penilaian (telah diberi surat } \\
\text { peringatan dan mutasi/dikeluarkan) } \\
\text { maupun pada masa kontrak, karena cukup } \\
\text { petunjuk bahwa pihak kedua belum mampu } \\
\text { menjalankan tugas sebagaimana mestinya. } \\
\text { Pekerja hanya dibayarkan gaji terakhir } \\
\text { sesuai jumlah hari kerja }\end{array}$ & & \\
\hline $\begin{array}{c}\text { Angka } \\
\text { (3) }\end{array}$ & $\begin{array}{l}\text { PT SIS dapat memutuskan hubungan kerja } \\
\text { dengan pihak kedua tanpa ada surat } \\
\text { peringatan 1, 2, } 3 \text { dan hal-hal lain apabila } \\
\text { ada pengurangan tenaga kerja sesuai } \\
\text { permintaan client ataupun kebutuhan di }\end{array}$ & & \\
\hline
\end{tabular}


Nommensen Journal of Legal Opinion (NJLO)

Jurnal Magister Hukum Program Pascasarjana Universitas HKBP Nommensen

Volume o2 Nomor o1 Januari 2021 Halaman. 55-79

e-ISSN: 2723-164X

p-ISSN: 2722-9858

http://ejournal.uhn.ac.id/index.php/opinion

\begin{tabular}{|c|c|c|c|}
\hline & $\begin{array}{l}\text { area tersebut dan Pekerja hanya dibayarkan } \\
\text { gaji terakhir sesuai jumlah hari kerja. }\end{array}$ & & \\
\hline $\begin{array}{c}\text { IV } \\
\text { angka } \\
(1)\end{array}$ & Upah dibayar secara bulanan. & $\begin{array}{l}\text { angka } \\
(5)\end{array}$ & $\begin{array}{l}\text { Bila tidak masuk kerja di } \\
\text { karenakan alpa (tidak ada surat } \\
\text { pendukung) maka akan dipotong } \\
\text { gaji pokok / jumlah hari kerja x } \\
\text { jumlah alpa. }\end{array}$ \\
\hline $\begin{array}{c}\text { angka } \\
(2)\end{array}$ & $\begin{array}{l}\text { Upah dibayarkan tanggal } 1 \text { setiap bulannya } \\
\text { atau jika pada tanggal yang telah } \\
\text { ditentukan jatuh pada hari libur, maka } \\
\text { upah akan dibayarkan pada waktu hari } \\
\text { kerja berikutnya setelah tanggal merah. }\end{array}$ & $\begin{array}{c}\text { angka } \\
(6)\end{array}$ & $\begin{array}{l}\text { Tenaga kerja baru yang masa } \\
\text { kerjanya kurang dari } 14 \text { hari kerja } \\
\text { maka gaji tidak akan dibayarkan. }\end{array}$ \\
\hline $\begin{array}{c}\text { angka } \\
\text { (3) }\end{array}$ & $\begin{array}{l}\text { Upah dibayarkan dengan cara mentransfer } \\
\text { upah yang telah disepakati melalui rekening } \\
\text { Bank yang telah ditunjuk oleh Pihak } \\
\text { Pertama. }\end{array}$ & $\begin{array}{c}\text { angka } \\
(7)\end{array}$ & $\begin{array}{l}\text { Tenaga kerja yang resign harus } \\
\text { mengajukan } 2 \text { minggu sebelum } \\
\text { resign, jika kurang dari } 2 \text { minggu } \\
\text { maka sisa gaji tidak akan } \\
\text { dibayarkan. }\end{array}$ \\
\hline $\begin{array}{c}\text { IV } \\
\text { Angka } \\
(4)\end{array}$ & $\begin{array}{l}\text { Bila tidak masuk kerja karena sakit atau izin } \\
\text { akan dipotong gaji pokok/jumlah hari kerja } \\
\mathrm{x} \text { jumlah sakit izin dan sakit (harus } \\
\text { disertakan surat pendukung). }\end{array}$ & $\begin{array}{c}\text { angka } \\
(8) \\
\text { angka } \\
\text { (9) }\end{array}$ & $\begin{array}{l}\text { Apabila karyawan dirumahkan } \\
\text { dalam waktu } 2 \text { minggu tidak } \\
\text { dipanggil maka dianggap } \\
\text { mengundurkan diri. } \\
\text { Apabila karyawan sudah tidak } \\
\text { aktif (resign atau mengundurkan } \\
\text { diri) maka tidak mendapatkan } \\
\text { pesangon atau uang terimakasih. }\end{array}$ \\
\hline $\begin{array}{c}\mathrm{V} \\
\text { angka } \\
(1)\end{array}$ & $\begin{array}{l}\text { Dalam hal pelanggaran yang dapat } \\
\text { merugikan Perusahaan, maka Pekerja } \\
\text { bersedia mengganti kerugian tersebut } \\
\text { kepada Perusahaan. }\end{array}$ & $\begin{array}{l}\text { angka } \\
(3)\end{array}$ & $\begin{array}{l}\text { Dalam hal terjadi pelanggaran } \\
\text { adalah apabila Pekerja melakukan } \\
\text { perusakan alat atau barang milik } \\
\text { Perusahaan atau milik proyek } \\
\text { dimana Pekerja ditempatkan yang } \\
\text { mengakibatkan kerugian bagi } \\
\text { Perusahaan atau proyek karena } \\
\text { kelalaian Pekerja, maka Pekerja } \\
\text { harus mengganti kerusakan dan } \\
\text { atau kerugian tersebut. } \\
\text { Dalam hal penggantian kerusakan } \\
\text { dan atau kerugian tersebut, maka } \\
\text { Pekerja akan membayar dengan }\end{array}$ \\
\hline
\end{tabular}


Jurnal Magister Hukum Program Pascasarjana Universitas HKBP Nommensen

Volume o2 Nomor o1 Januari 2021 Halaman. 55-79 e-ISSN: 2723-164X p-ISSN: 2722-9858

http://ejournal.uhn.ac.id/index.php/opinion

\begin{tabular}{|c|l|l|l|}
\hline & & & $\begin{array}{l}\text { cara mencicil 50\% dari gaji yang } \\
\text { diterima oleh Pihak Kedua sampai } \\
\text { lunas kepada Pihak Pertama. }\end{array}$ \\
\hline $\begin{array}{c}\text { angka } \\
(2)\end{array}$ & $\begin{array}{l}\text { Untuk kasus pencurian atau penipuan baik } \\
\text { melakukan atau terlibat langsung atau tidak } \\
\text { langsung akan denda (sepuluh) kali lipat } \\
\text { dari harga barang tersebut, dan akan } \\
\text { diproses melalui jalur hukum. }\end{array}$ & & \\
\hline
\end{tabular}

Berdasarkan tabel di atas, jelas sekali hak Perusahaan Outsourcing lebih banyak dari pada Pekerja, hal ini menunjukkan ketidakseimbangan kedudukan pekerja yang subordinat di bawah perusahaan/pengusaha.

Selain yang sudah penulis uraikan pada legalitas PKWT dan Perjanjian Penyedia Jasa Pekerja sebelumnya, dari hak dan kewajiban dalamtabel diatas, penulis menemukan beberapa hal yang bertentangan dengan UU Ketenagakerjaan pasca UU Cipta Kerja, yaitu:

1. Terkait dengan Pasal IV tentang pengupahan pada bagian ke 6 (enam) yang berbunyi "tenaga kerja baru yang masa kerjanya kurang dari 14 (empat belas) hari kerja maka gaji tidak akan dibayarkan” didalam Pasal 58 UU Cipta Kerja Bab IV tentang Ketenagakerjaan secara tegas dikatakan bahwa :

1) Perjanjian kerja untuk waktu tertentu tidak dapat mensyarakatkan adanya masa percobaan kerja.

2) Dalam hal disyaratkan masa percobaan kerja sebagaimana dimaksud pada ayat (1), masa percobaan kerja yang disyaratkan tersebut batal demi hukum dan masa kerja tetap dihitung.

2. Selanjutnya pada bagian yang ke 8 (delapan) yang berbunyi "apabila karyawan dirumahkan dalam waktu 2 minggu tidak dipanggil maka akan dianggap mengundurkan diri” perjanjian kerja ini dibuat pada awal bulan Maret 2020 tepat dimana pandemi covid-19 sudah masuk ke Indonesia dan keadaan ini termasuk dalam force majeure, walaupun keadaan ini diluar dari kendali para pihak namun PT SIS tidak boleh serta merta menganggap apabila karyawan dirumahkan dan tidak dipanggil dianggap mengundurkan diri, ketentuan sepihak yang dibuat oleh PT SIS yang merugikan para pekerjanya ini sudah bertentangan dengan UU Cipta Kerja. Dimana pekerja yang dirumahkan masih dalam tanggungjawab PT SIS untuk memberikan upah dan apabila hubungan kerja ingin diakhiri maka seharusnya PT SIS memberikan kompensasi kepada para pekerjanya bukan menganggap para pekerjanya mengundurkan diri dan melepaskan tanggungjawab untuk memberikan uang kompensasi.

Dari hasil wawancara saya dengan Ibu Eka Adyati, saya selaku penulis menemukan bahwa di PT SIS ada melakukan Pemutusan Hubungan Kerja (PHK) terhadap tenaga kerja outsourcing mereka, namun untuk jumlah pastinya beliau tidak mengetahui berapa banyak. Adapun hak-hak yang diberikan PT SIS terhadap tenaga kerja outsourcing yang diputus Hubungan Kerja adalah berupa gaji terakhir sebelum dilakukan PHK dan uang pesangon. 
Hal ini sudah sesuai dengan yang diamanatkan dalam ketentuan UU Ketenagakerjaan juncto Pasal 40 ayat (1) bagian kedua Peraturan Pemerintah Republik Indonesia Nomor 35 Tahun 2021 Tentang Perjanjian Kerja Waktu Tertentu, Alih Daya, Waktu Kerja dan Waktu Istirahat, dan Pemutusan Hubungan Kerja Pasal 40 ayat 1 bagian kedua, Hak Akibat Pemutusan Hubungan Kerja. Dimana pasal 40 ayat 1 menyatakan:

"Dalam hal terjadi Pemutusan Hubungan Kerja, Pengusaha wajib membayarkan uang pesangon dan/atau uang penghargaan masa kerja, dan uang penggantian hak yang harus diterima”. Akan tetapi ini adalah untuk Pekerja yang terikat dengan PKWTT.

Setelah berlakunya PP No. 35 Tahun 2021, maka untuk pekerja yang PKWT nya berakhir memperoleh Uang Kompensasi sebagaimana akan diuraikan pada bagian analisis selanjutnya.

\section{Analisis Tanggung Jawab Perusahaan Alih Daya terhadap Pekerja outsourcing yang} Diputus hubungan Kerjanya di Masa Pandemi Covid-19.

Berdasarkan hasil penelitian penulis berupa data pada tabel hak dan kewajiban di atas, dan hasil wawancara penulis dengan tenaga kerja outsourcing PT Sinergi Integra Services yang bekerja di PT Nasional Tetap Unggulan, maka penulis dapat menganalisis mengenai Tanggung Jawab Perusahaan alih daya terhadap pekerja/buruh outsourcing yang diputus hubungan kerjanya di masa pandemi covid-19.

1. PHK Setelah PKWT Berakhir dalam Pasal 61A UU Ketenagakerjaan Pasca UU Cipta kerja jo. Pasal 15 PP No. 35 Tahun 2021 Tentang PKWT, Alih Daya, Waktu Kerja dan Waktu Istirahat, dan PHK.

Dalam Pasal 61 A UU Ketenagakerjaan pasca UU Cipta Kerja secara tegas mengatakan bahwa dalam hal PKWT berakhir, pengusaha wajib memberikan uang kompensasi kepada pekerja/buruh sesuai dengan masa kerja pekerja/buruh di perusahaan yang bersangkutan.

Ketentuan pelaksanannya diatur dalam Peraturan Pemerintah No. 35 Tahun 2021 yakni Bagian Ketiga, Pasal 15 mengenai Pemberian Uang Kompensasi berbunyi sebagai berikut:

1. Pengusaha wajib memberikan uang kompensasi kepada Pekerja/Buruh yang hubungan kerjanya berdasarkan PKWT.

2. Pemberian uang kompensasi dilaksanakan pada saat berakhirnya PKWT.

3. Uang kompensasi sebagaimana dimaksud pada ayat (1) diberikan kepada Pekerja/Buruh yang telah mempunyai masa kerja paling sedikit 1 (satu) bulan secara terus menerus.

4. Apabila PKWT diperpanjang, uang kompensasi diberikan saat selesainya jangka waktu PKWT sebelum perpanjangan dan terhadap jangka waktu perpanjangan PKWT, uang kompensasi berikutnya diberikan setelah perpanjangan jangka waktu PKWT berakhir atau selesai.

5. Pemberian uang kompensasi tidak berlaku bagi tenaga kerja asing yang dipekerjakan oleh pemberi kerja dalam Hubungan Kerja berdasarkan PKWT

2. PHK sebelum PKWT berakhir Pasal 62 UU Ketenagakerjaan, dikaitkan dengan pandemic covid-19 (force majeur).

Pasal 62 UU Ketenagakerjaan mengatur terkait dengan pemutusan hubungan kerja sebelum perjanjian kerja waktu tertentu berakhir, dalam pasal tersebut dikatan bahwa "Apabila salah satu pihak mengakhiri hubungan kerja sebelum berakhirnya jangka waktu yang ditetapkan dalam perjanjian kerja waktu tertentu, atau berakhirnya hubungan kerja bukan karena ketentuan sebagaimana dimaksud dalam Pasal 61 ayat (1), pihak yang mengakhiri hubungan kerja diwajibkan membayar ganti 
rugi kepada pihak lainnya sebesar upah pekerja/buruh sampai batas waktu berakhirnya jangka waktu perjanjian".

Bila dikaitkan dengan force majeur atau keadaan memaksa diluar kendali kemampuan manusia sehingga menimbulkan dapat kerugian dari para pihak maka pandemi covid-19 ini termasuk force majeur. Dalam Surat Edaran Menteri Ketenagakerjaan Nomor M/3/HK.04/III/2020 Tahun 2020 tentang Perlindungan Pekerja/Buruh dan kelangsungan Usaha dalam Rangka Pencegahan dan

Penanggulangan Covid-19. Menteri Ketenagakerjaan meminta kepada para gubernur untuk melaksanakan perlindungan pengupahan bagi pekerja/buruh terkait pandemi Covid-19, sebagai berikut:

1. Bagi pekerja/buruh yang dikategorikan sebagai Orang Dalam Pemantauan (ODP) Covid-19 berdasarkan keterangan dokter sehingga tidak dapat masuk kerja paling lama 14 hari atau sesuai standar Kementerian Kesehatan, maka upahnya dibayarkan penuh.

2. Bagi pekerja/buruh yang dikategorikan kasus suspek Covid-19 dan dikarantina/diisolasi menurut keterangan dokter, maka upahnya dibayarkan secara penuh selama menjalani masa karantina/isolasi.

3. Bagi pekerja/uruh yang tidak masuk kerja karena sakit Covid-19 dan dibuktikan dengan keterangan dokter, maka upahnya dibayarkan sesuai peraturan perundang-undangan.

4. Bagi perusahaan yangmelakukan pembatasan kegiatan usaha akibat kebijakan pemerintah di daerah masing-masing guna pencegahan dan penanggulangan Covid-19, sehingga meyebabkan sebagian atau seluruh pekerja/buruhnya tidak masuk kerja, dengan mempertimbangkan kelangsungan usaha maka perubahan besaran maupun cara pembayaran upah pekerja/buruh dilakukan sesuai dengan kesepakatan antara pengusaha dengan pekerja/buruh.

Berdasarkan surat edaran tersebut, untuk menghindari PHK, pengusaha dapat melakukan perubahan besaran maupun cara pembayaran upah pekerja/buruh yang dirumahkan sementara akibat wabah Covis-19, berdasarkan kesepakatan para pihak. Selain itu, pekerja/buruh yang positif terjangkit Covid-19 juga berhak atas upah.

Terkait ketentuan dengan ganti rugi bagi pekerja dengan PKWT jika pekerja PKWT di PHK secara sepihak ditengah masa kontraknya, pekerja PKWT berhak mendapat ganti rugi sejumlah sisa masa kontrak tersebut namun tidak berhak atas pesangon atau uang kompensasi.

Realisasi hak-hak pekerja akibat PHK ternyata mengalami hambatan. Hasil wawancara penulis dengan pihak SPSI Medan Bapak Nelson Manalu, penulis mendapat beberapa informasi yaitu terkait mengenai peran SPSI dalam dunia ketenagakerjaan adalah salah satunya adalah mendampingi pekerja dalam memperoleh hak-haknya dari perusahaan tempat dimana pekerja bekerja, namun yang menjadi penghambat dari tujuan SPSI untuk mendampingi para pekerja adalah kurangnya keberanian para pekerja untuk melaporkan kepada SPSI tentang hal-hal yang terjadi di tempat pekerja bekerja. Berkenaan dengan hal diatas Ibu Ririn dari Dinas Ketenagakerjaan menambahkan terkait mengenai penyelesaian perselisihan hubungan kerja, beliau mengatakan untuk eksekusi dari Pengadilan Hubungan Industrial tidak dapat dituntut, sehingga perlu kepastian perlindungan hukum bagi Pekerja, terutama pekerja outsourcing yang terkena PHK di masa pandemic covid-19.

Perlindungan Hukum Terhadap pekerja/buruh outsourcingyang di-PHKSebelum dan Pasca UU No. 11 tahun 2020 Tentang Cipta Kerja. 
Nommensen Journal of Legal Opinion (NJLO)

Jurnal Magister Hukum Program Pascasarjana Universitas HKBP Nommensen

Volume o2 Nomor o1 Januari 2021 Halaman. 55-79 e-ISSN: 2723-164X p-ISSN: 2722-9858

http://ejournal.uhn.ac.id/index.php/opinion

Pasal 66 ayat (2) huruf b UU Ketenagakerjaan sebelum UU Cipta Kerja jo. Pasal 66 (1) UU ketenagakerjaan pasca UU Cipta Kerja, pekerja outsourcing dapat berupa PKWT atau PKWTT.

Dalam hal pemutusan hubungan kerja, baik pemutusan hubungan kerja yang diatur dalam UU Ketenagakerjaan, maupun pemutusan hubungan kerja yang diatur dalam UU Cipta Kerja Bagian IV Ketenagakerjaan. Dapat dilihat perbedaannya melalui pasal-pasal yang penulis susun pada tabel berikut.

\section{Untuk Pekerja Outsource dengan PKWTT}

\section{Tabel 4.3. Perlindungan Hak-Hak Pekerja PKWTT berdasarkan UU Ketenagakerjaan dan sesudah UU Cipta Kerja}

\begin{tabular}{|c|c|c|c|}
\hline No. & Topik & UU Ketenagakerjaan & UU Cipta Kerja \\
\hline 1 & Uang Pengganti Hak & Diatur dalam pasal 156 (4) & $\begin{array}{l}\text { Tidak adanya uang } \\
\text { pengganti hak }\end{array}$ \\
\hline 2 & $\begin{array}{l}\text { Uang Penghargaan } \\
\text { Masa Kerja }\end{array}$ & $\begin{array}{l}\text { Diatur dalam pasal } 156 \text { (3) } \\
\text { UUKetenagakerjaan }\end{array}$ & $\begin{array}{l}\text { Uang penghargaan masa } \\
\text { kerja } 24 \text { tahun dihapus. UU } \\
\text { Cipta Kerja menghapus poin } \\
\text { H dalam pasal } 156 \text { ayat } 3 \\
\text { terkait uang penghargaan } \\
\text { bagi pekerja/buruh yang } \\
\text { memiliki masa kerja } 24 \\
\text { tahun atau lebih dimana } \\
\text { seharusnya pekerja/buruh } \\
\text { menerima uang penghargaan } \\
\text { sebanyak oo bulan upah. }\end{array}$ \\
\hline 3 & Uang Pesangon & $\begin{array}{l}\text { Pasal 161 UUK } \\
\text { menyebutkan: } \\
\text { Dalam hal pekerja/buruh } \\
\text { melakukan pelanggaran } \\
\text { ketentuan yang diatur } \\
\text { dalam perjanjian kerja, } \\
\text { peraturan perusahaan atau } \\
\text { perjanjian kerja bersama, } \\
\text { pengusaha dapat } \\
\text { melakukan pemutusan } \\
\text { hubungan kerja, setelah } \\
\text { kepada pekerja/buruh yang } \\
\text { bersangkutan diberikan } \\
\text { surat peringatan pertama, } \\
\text { kedua, dan ketiga secara } \\
\text { berturut-turut. } \\
\text { Pasal 163 (1) UUK } \\
\text { menyebutkan: pengusaha } \\
\text { dapat melakukan } \\
\text { pemutusan hubugan kerja } \\
\text { terhadap pekerja/buruh } \\
\text { dalam hal perubahan } \\
\text { status, penggabungan, }\end{array}$ & $\begin{array}{l}\text { *Menghapuskan uang } \\
\text { pesangon bagi pekerja/buruh } \\
\text { yang di PHK karena surat } \\
\text { peringatan. Padahal dalam } \\
\text { UUK pasal 161 menyebutkan } \\
\text { pekerja/buruh yang di PHK } \\
\text { karena mendapat surat } \\
\text { peringatan memiliki hak } \\
\text { mendapat pesangon. } \\
\text { *Menghapuskan uang } \\
\text { pesangon bagi pekerja/buruh } \\
\text { yang di PHK karena } \\
\text { peleburan, pergantian status } \\
\text { kepemilikan perusahaan. } \\
\text { Pekerja/buruh yang di PHK } \\
\text { karena pergantian status } \\
\text { kepemilikan perusahaan } \\
\text { tidak akan diberi pesangon } \\
\text { lagi oleh perusahaan awal, } \\
\text { sebab hal ini sudah dihapus } \\
\text { dalam UU Cipta Kerja. } \\
\text { *Menghapuskan uang } \\
\text { pesangon bagi pekerja/buruh } \\
\text { yang di PHK karena } \\
\text { perusahaan merugi } 2 \text { tahun }\end{array}$ \\
\hline
\end{tabular}




\begin{tabular}{|c|c|c|c|}
\hline & & $\begin{array}{l}\text { peleburan, atau perubahan } \\
\text { kepemilikan perusahaan } \\
\text { dan pekerja/buruh tidak } \\
\text { bersedia melanjutkan } \\
\text { hubungan kerja, maka } \\
\text { pekerja/buruh berhak atas } \\
\text { uang pesangon sebesar } 1 \\
\text { (satu) kali ketentuan Pasal } \\
156 \text { ayat (2), uang } \\
\text { penghargaan masa kerja } 1 \\
\text { (satu) kali ketentuan Pasal } \\
156 \text { ayat (3) dan uang } \\
\text { penggantian hak sesuai } \\
\text { ketentuan Pasal } 156 \text { ayat } \\
\text { (4). } \\
\text { Pasal } 164 \text { dan } 165 \text { UUK } \\
\text { mengatur mengenai } \\
\text { pekerja/buruh yang di PHK } \\
\text { karena perusahaan merugi } \\
\text { dan pailit berhak mendapat } \\
\text { pesangon. Pasal } 166 \text { UUK } \\
\text { mengatur hak keluarga } \\
\text { buruh atau pekerja. Bila } \\
\text { buruh atau pekerja } \\
\text { meninggal dunia, } \\
\text { pengusaha harus } \\
\text { memberikan uang kepada } \\
\text { ahli waris. Pasal } 167 \text { UUK } \\
\text { mengatur mengenai } \\
\text { pesangon untuk } \\
\text { pekerja/buruh yang di PHK } \\
\text { karena memasuki usia } \\
\text { pensiun. }\end{array}$ & $\begin{array}{l}\text { dan pailit. Pemerintah telah } \\
\text { menghapuskan UU } \\
\text { Ketenagakerjaan Pasal } 164 \\
\text { dan } 165 \text { di dalam UU Cipta } \\
\text { Kerja. Jadi nantinya } \\
\text { pekerja/buruh yang di PHK } \\
\text { karena perusahaan } \\
\text { mengalami kerugian dan } \\
\text { pailit tidak mendapat } \\
\text { pesangon. } \\
\text { *Menghapuskan uang } \\
\text { santunan berupa pesangon } \\
\text { bagi ahli waris atau keluarga } \\
\text { apabila pekerja/buruh } \\
\text { meninggal. UU Cipta Kerja } \\
\text { juga telah menghapuskan } \\
\text { pemberian uang santunan } \\
\text { berupa pesangon, hak uang } \\
\text { penghargaan masa kerja dan } \\
\text { uang penggantian hak bagi } \\
\text { ahli waris yang ditinggalkan. } \\
\\
\text { *Menghapuskan uang } \\
\text { pesangon bagi pekerja/buruh } \\
\text { yang di PHK karena akan } \\
\text { memasuki usia pensiun. } \\
\text { Pemerintah telah menghapus } \\
\text { Pasal 167 UUK yang isinya } \\
\text { mengatur pesangon bagi } \\
\text { pekerja/buruh yang di PHK } \\
\text { karena memasuki usia } \\
\text { pensiun. }\end{array}$ \\
\hline 4 & $\begin{array}{c}\text { Jaminan Kehilangan } \\
\text { Pekerjaan }\end{array}$ & $\begin{array}{l}\text { Tidak diatur dalam UUK } \\
\text { sebelumnya. }\end{array}$ & $\begin{array}{l}\text { Menambahkan program } \\
\text { jaminan sosial baru yaitu } \\
\text { Jaminan Kehilangan } \\
\text { Pekerjaan atau yang sering } \\
\text { disingkat dengan JKP yang } \\
\text { dikelola oleh BPJS } \\
\text { Ketenagakerjaan } \\
\text { berdasarkan prinsip asuransi } \\
\text { sosial. } \\
\text { Pasal } 2 \text { PP No. } 37 \text { Tahun } 2021 \\
\text { menyatakan Pengusaha } \\
\text { wajib mengikutsertakan } \\
\text { Pekerja sebagai Peserta } \\
\text { dalam Program JKP yang } \\
\text { diselenggarakan untuk }\end{array}$ \\
\hline
\end{tabular}


Nommensen Journal of Legal Opinion (NJLO)

Jurnal Magister Hukum Program Pascasarjana Universitas HKBP Nommensen

Volume o2 Nomor o1 Januari 2021 Halaman. 55-79 e-ISSN: 2723-164X p-ISSN: 2722-9858

http://ejournal.uhn.ac.id/index.php/opinion

\begin{tabular}{|c|c|c|c|}
\hline & & & $\begin{array}{l}\text { mempertahankan derajat } \\
\text { kehidupan yang layak pada } \\
\text { saat pekerja kehilangan } \\
\text { pekerjaan. }\end{array}$ \\
\hline 5 & $\begin{array}{l}\text { Jenis Pemutusan } \\
\text { Hubungan Kerja }\end{array}$ & $\begin{array}{l}\text { Melihat pada UU } \\
\text { Ketenagakerjaan, ada } 9 \\
\text { alasan perusahaan boleh } \\
\text { melakukan PHK seperti: } \\
\text { a. Perusahaan bangkrut } \\
\text { b. Perusahaan tutup } \\
\text { karena merugi } \\
\text { c. Perubahan status } \\
\text { perusahaan } \\
\text { d. Pekerja/buruh } \\
\text { melanggar perjanjian kerja } \\
\text { e. Pekerja/buruh } \\
\text { melakukan kesalahan berat } \\
\text { f. Pekerja/buruh } \\
\text { memasuki usia pensiun } \\
\text { g. Pekerja/buruh } \\
\text { mengundurkan diri } \\
\text { h. Pekerja/buruh } \\
\text { meninggal dunia } \\
\text { i. Pekerja/buruh mangkir }\end{array}$ & $\begin{array}{l}\text { UU Cipta Kerja } \\
\text { menambahkan } 5 \text { poin lagi } \\
\text { alasan perusahaan boleh } \\
\text { melakukan PHK, diantaranya } \\
\text { meliputi: } \\
\text { a. Perusahaan melakukan } \\
\text { efisiensi } \\
\text { b. Perusahaan melakukan } \\
\text { penggabungan, peleburan, } \\
\text { pengambialihan, atau } \\
\text { pemisahan perusahaan } \\
\text { c. Perusahaan dalam } \\
\text { keadaan penundaan } \\
\text { kewajiban pembayaran utang } \\
\text { d. Perusahaan melakukan } \\
\text { perbuatan yang merugikan } \\
\text { pekerja/buruh } \\
\text { e. Pekerja/buruh mengalami } \\
\text { sakit berkepanjangan atau } \\
\text { cacat akibat kecelakaan kerja } \\
\text { dan tidak dapat melakukan } \\
\text { pekerjaannya setelah } \\
\text { melampaui batas } 12 \text { bulan }\end{array}$ \\
\hline
\end{tabular}

Perlindungannya bagi pekerja outsourcing dengan PKWTT di dalam UU Cipta Kerja ini adalah bahwa adanya pemberian Jaminan Kehilangan Pekerjaan yang dikelola oleh BPJS Ketenagakerjaan diberikan kepada pekerja/buruh yang mengalami pemutusan hubungan kerja (PHK) berupa manfaat uang tunai, akses informasi pasar kerja, dan pelatihan kerja

Iuran program JKP wajib dibayar setiap bulan sebesar 0,46 persen dari upah bulanan pekerja/buruh. Sekitar 0,22 persen dari jumlah iuran akan dibayar oleh pemerintah. Sisanya, dibayar oleh sumber pendanaan JKP yang merupakan rekomposisi dari iuran program JKK dan JKM yang sebelumnya sudah ada dan berlaku di BPJS Ketenagakerjaan. Iuran JKK direkomposisi o,14 persen dan iuran JKM o,1 persen dari upah sebulan. ${ }^{9}$

Manfaat diberikan ke peserta yang mengalami PHK untuk hubungan kerja berdasarkan perjanjian kerja waktu tertentu maupun tidak tertentu asal peserta mau bekerja lagi di tempat lain setelah pemutusan. Manfaat bisa diambil bila peserta sudah menyelesaikan iuran paling sedikit 12 bulan dalam 24 bulan atau setidaknya sudah membayar iuran enam bulan berturutturut sebelum terjadi PHK. Manfaat JKP tak bisa diterima pekerja/buruh bila yang bersangkutan mengundurkan diri sendiri, cacat total tetap, pensiun, hingga meninggal dunia. Pekerja/buruh akan langsung menerima manfaat program bila sudah di-PHK sebelum kontrak perjanjian kerja selesai.

Syarat pencairan manfaat, yaitu bukti diterimanya PHK oleh pekerja/buruh, tanda terima lapor PHK dari dinas ketenagakerjaan kabupaten/kota, perjanjian bersama yang telah

\footnotetext{
${ }^{9}$ https://gajimu.com/pekerjaan-yanglayak/jaminan-sosial/BPJS/jaminan-kehilangan-pekerjaan-jkp, diakses pada tanggal 16 Maret 2021
} 
didaftarkan ke pengadilan hubungan industrial, akta bukti pendaftaran perjanjian bersama, hingga petikan putusan pengadilan.

Selanjutnya, manfaat diberikan dalam tiga bentuk. Pertama, uang tunai paling banyak enam bulan yang diberikan setiap bulan. Terbagi atas 45 persen dari upah untuk tiga bulan pertama dan 25 persen untuk tiga bulan berikutnya.

Bila upah yang diterima tidak sesuai dengan yang sebenarnya, sehingga ada kekurangan pembayaran manfaat uang tunai, maka pengusaha wajib membayar kekurangan manfaat uang tunai ke pekerja/buruh secara sekaligus.

Kedua, manfaat dalam bentuk akses informasi pasar kerja berupa informasi dan bimbingan jabatan oleh petugas antarkerja melalui sistem informasi ketenagakerjaan. Informasi pasar kerja berupa lowongan, sedangkan bimbingan dalam bentuk asesmen atau konseling karir. Ketiga, manfaat pelatihan kerja. Manfaat diberikan secara online maupun offline melalui lembaga pelatihan kerja milik pemerintah, swasta, atau perusahaan yang sudah terverifikasi oleh sistem informasi ketenagakerjaan.

Lembaga pelatihan dapat bekerja sama dengan lembaga sertifikasi profesi untuk uji kompetensi yang berlisensi dari badan nasional sertifikasi profesi. Manfaat ini dilaksanakan oleh pemerintah di bidang ketenagakerjaan.

2. Untuk Pekerja Outsourcing dengan PKWT

b. Perlindungan adanya jaminan kelangsungan pekerjaan bila pekerjaan masih ada (Pasal 66 (3) UUK pasca UU Cipta Kerja) jo. Putusan MK No. 27/PUUIX/2011(PP No. 35 Tahun 2021 terkait Kompensasi)

Tabel 4.4. Perlindungan Hak-Hak Pekerja PKWT berdasarkan UUKetenagakerjaandan sesudah UU Cipta Kerja

\begin{tabular}{|c|c|c|c|}
\hline No. & Topik & UU Ketenagakerjaan & UU Cipta Kerja \\
\hline 1 & $\begin{array}{c}\text { Jangka waktu } \\
\text { PKWT }\end{array}$ & $\begin{array}{l}\text { Pasal } 59 \text { UUK } \\
\text { mengatur Perjanjian } \\
\text { Kerja Waktu Tertentu } \\
\text { (PKWT) terhadap } \\
\text { pekerja itu maksimal } \\
\text { dilakukan selama } 2 \\
\text { tahun, lalu boleh } \\
\text { diperpanjang kembali } \\
\text { dalam waktu } 1 \text { tahun. } \\
\text { Dengan demikian } \\
\text { jangka waktu PKWT } \\
\text { paling lama } 3 \text { tahun. }\end{array}$ & $\begin{array}{l}\text { Menghapus Pasal } 59 \text { UUK } \\
\text { yang mengatur tentang } \\
\text { syarat pekerja waktu tertentu } \\
\text { atau pekerja kontrak. Pada } \\
\text { Pasal } 8 \text { jo. Pasal } 5 \text { ayat (1) PP } \\
\text { No. } 35 \text { Tahun } 2021 \text { ditetapkan } \\
\text { untuk PKWT didasarkan } \\
\text { jangka waktu dengan } \\
\text { pekerjaan tertentu yakni } \\
\text { untuk pekerjaan yang } \\
\text { diperkitrakan tidak terlalu } \\
\text { lama; pekerjaan bersifat } \\
\text { musiman dan pekerjaan yang } \\
\text { berhubungan dengan produk } \\
\text { baru, kegiatan baru, atau } \\
\text { produk tambahan yang } \\
\text { masih dalam masa percobaan } \\
\text { dapat dibuat paling lama } 5 \\
\text { tahun termasuk } \\
\text { perpanjangannya. }\end{array}$ \\
\hline
\end{tabular}


Jurnal Magister Hukum Program Pascasarjana Universitas HKBP Nommensen

Volume o2 Nomor o1 Januari 2021 Halaman. 55-79 e-ISSN: 2723-164X p-ISSN: 2722-9858

http://ejournal.uhn.ac.id/index.php/opinion

\begin{tabular}{|c|c|c|c|}
\hline & & & $\begin{array}{l}\text { Mengatur tentang Uang } \\
\text { Kompensasi ketika PKWT } \\
\text { berakhir. }\end{array}$ \\
\hline 2 & Outsourcing: & $\begin{array}{l}\text { la } \\
\text { Aturan UU } \\
\text { Ketenagakerjaan } \\
\text { dalam penggunaan } \\
\text { outsourcing dibatasi } \\
\text { dan hanya untuk } \\
\text { tenaga kerja di luar } \\
\text { usaha pokok, yakni : } \\
\text { Cleaning service, } \\
\text { security, catering jasa } \\
\text { angkutan pekerja, dan } \\
\text { pekerjaan penunjang } \\
\text { di sector } \\
\text { pertambangan. }\end{array}$ & $\begin{array}{l}\text { Jenis Pekerjaan: } \\
\text { UU Cipta Kerja akan } \\
\text { membuka kemungkinan bagi } \\
\text { lembaga outsourcing untuk } \\
\text { mempekerjakan pekerja } \\
\text { untuk berbagi tugas, } \\
\text { termasuk pekerja lepas dan } \\
\text { pekerja paruh waktu. Hal ini } \\
\text { akan membuat penggunaan } \\
\text { tenaga ahli daya semakin } \\
\text { bebas. } \\
\text { Perlindungan jaminan } \\
\text { kelangsungan bekerja: } \\
\text { Dalam hal perusahaan alih } \\
\text { daya memperkerjakan } \\
\text { pekerja/buruh berdasarkan } \\
\text { PKWT, maka perjanjian kerja } \\
\text { tersebut harus mensyaratkan } \\
\text { pengalihan perlindungan } \\
\text { hak-hak bagi pekerja/buruh } \\
\text { apabila terjadi pergantian } \\
\text { perusahaan alih daya dan } \\
\text { sepanjang objek } \\
\text { pekerjaannya tetap ada. }\end{array}$ \\
\hline
\end{tabular}

Setelah penulis menganalisis mengenai bentuk perlindungan bagi pekerja PKWTT, selanjutnya penulis akan menganalisis mengenai bentuk perlindungan hukum bagi pekerja PKWT. Pasal 66 ayat (3) UU Cipta Kerja mengatakan bahwa "Dalam hal perusahaan alih daya memperkerjakan pekerja/buruh berdasarkan perjanjian kerja waktu tertentu sebagaimana dimaksud pada ayat (1), perjanjian kerja tersebut harus mensyaratkan pengalihan perlindungan hak-hak bagi pekerja/buruh apabila terjadi pergantian perusahaan alih daya dan sepanjang objek pekerjaannya tetap ada".

Didalam Putusan MK No. 27/PUU-IX/2011, Mahkamah Konstitusi menyatakan "dalam hal buruh dimaksud ternyata dipekerjakan untuk melaksanakan kegiatan pokok, tidak ada 
hubungan kerja dengan perusahaan penyedia jasa pekerja/buruh bukan merupakan bentuk usaha berbadan hukum, maka demi hukum status hubungan kerja antara pekerja/buruh dan perusahaan penyedia jasa beralih menjadi hubungan kerja antara pekerja/buruh dengan perusahaan pemberi pekerjaan.

Sebagaimana diatur Pasal 66 Undang-Undang a quo, mendapat perlindungan kerja dan syarat-syarat yang sama perlindungan kerja dan syarat-syarat kerja pada perusahaan pemberi pekerjaan atau sesuai dengan peraturan perundang-undangan yang berlaku. Oleh karenanya, terlepas dari jangka waktu tertentu yang mungkin menjadi syarat perjanjian kerja demikian dalam kesempatan yang tersedia maka perlindungan hak-hak buruh sesuai dengan aturan hukum dalam UU Ketenagakerjaan" dalam putusan Mahkamah Konstitusi diatas peneliti menemukan bahwa pekerja baik PKWT maupun PKWTT bentuk perlindungan hak-hak pekerja telah diatur didalam UU.

Terkait uang kompensasi bagi pekerja PKWT telah diatur dalam PP No.35 Tahun 2021, pada Pasal 15 yang berbunyi sebagai berikut:

1. Pengusaha wajib memberikan uang kompensasi kepada Pekerja/Buruh yang hubungan kerjanya berdasarkan PKWT.

2. Pemberian uang kompensasi dilaksanakan pada saat berakhirnya PKWT.

3. Uang kompensasi sebagaimana dimaksud pada ayat (1) diberikan kepada Pekerja/Buruh yang telah mempunyai masa kerja paling sedikit 1 (satu) bulan secara terus menerus.

4. Apabila PKWT diperpanjang, uang kompensasi diberikan saat selesainya jangka waktu PKWT sebelum perpanjangan dan terhadap jangka waktu perpanjangan PKWT, uang kompensasi berikutnya diberikan setelah perpanjangan jangka waktu PKWT berakhir atau selesai.

5. Pemberian uang kompensasi tidak berlaku bagi tenaga kerja asing yang dipekerjakan oleh pemberi kerja dalam Hubungan Kerja berdasarkan PKWT.

Besaran uang kompensasi diberikan sesuai dengan ketentuan sebagai berikut (Pasal 16 PP No. 35 Tahun 2021) :

a. PKWT selama 12 (dua belas) bulan secara terus menerus, diberikan (satu) bulan upah;

b. PKWT selama 1 (satu) bulan atau lebih tetapi kurang dari 12 (dua belas) bulan, dihitung secara proporsional dengan perhitungan :

c. masa kerja X 1 (satu) 12 bulan upah; $\quad \mathrm{X}$

d. PKWT selama lebih dari 12 (dua belas) bulan dihitung secara proporsional dengan perhitungan : masa kerja x 1 (satu) 12 bulan upah;

\section{D.Kesimpulan}

Berdasarkan seluruh pembahasan pada bab sebelumnya dapat disimpulkan hal-hal sebagai berikut:

1. Tanggung Jawab Perusahaan alih daya terhadap pekerja/buruh outsourcing yang diputus hubungan kerjanya di masa pandemi covid-19 adalah sebagai berikut:

a. Bahwa PT SIS tetap memberikan gaji terakhir bagi tenaga kerja outsourcing yang telah di PHK dan memberikan uang pesangon namun tidak pada semua pekerjanya, hanya pada pekerja yang telah lama bekerja pada PT SIS. 
b. Baik dalam UU Ketenagakerjaan maupun UU Cipta Kerja telah diatur mengenai uang pesangon, uang penghargaan masa kerja dan uang penggantian hak atau uang kompensasi bagi pekerja yang di PHK.

c. Dalam hal PHK di masa Pandemi Covid-19 (force majeur) uang kompensasi tidak diharuskan diberikan oleh perusahaan alih daya, hanya uang kompensasi selama sisa masa kontrak yang wajib diberikan oleh perusahaan alih daya sesuai dengan SE Menteri Ketenagakerjaan Nomor M/3/HK.04/III/2020 Tahun 2020 tentang Perlindungan Pekerja/Buruh dan kelangsungan Usaha dalam Rangka Pencegahan dan Penanggulangan Covid-19.

2. Perbandingan bentuk perlindungan hukum terhadap pekerja/buruh outsourcing terkait dengan pemutusan hubungan kerja menurut UU No. 13 Tahun 2003 Tentang Ketenagakerjaan dan UU No. 11 tahun 2020 Tentang Cipta Kerja, adalah:

a. Terkait mengenai pesangon dalam pemutusan hubungan kerja dalam UndangUndang Cipta Kerja menghapuskan uang pesangon bagi pekerja/buruh yang di PHK karena surat peringatan. Padahal dalam UU Ketenagakerjaan pasal 161 menyebutkan pekerja/buruh yang di PHK karena mendapat surat peringatan memiliki hak mendapat pesangon. menghapuskan uang pesangon bagi pekerja/buruh yang di PHK karena peleburan, pergantian status kepemilikan perusahaan. Pekerja/buruh yang di PHK karena pergantian status kepemilikan perusahaan tidak akan diberi pesangon lagi oleh perusahaan awal, sebab hal ini sudah dihapus dalam UU Cipta Kerja. Menghapuskan uang pesangon bagi pekerja/buruh yang di PHK karena perusahaan merugi 2 tahun dan pailit. Pemerintah telah menghapuskan UU Ketenagakerjaan Pasal 164 dan 165 di dalam UU Cipta Kerja. Jadi nantinya pekerja/buruh yang di PHK karena perusahaan mengalami kerugian dan pailit tidak mendapat pesangon. menghapuskan uang santunan berupa pesangon bagi ahli waris atau keluarga apabila pekerja/buruh meninggal. UU Cipta Kerja juga telah menghapuskan pemberian uang santunan berupa pesangon, hak uang penghargaan masa kerja dan uang penggantian hak bagi ahli waris yang ditinggalkan. Menghapuskan uang pesangon bagi pekerja/buruh yang di PHK karena akan memasuki usia pensiun. Pemerintah telah menghapus Pasal 167 UUK yang isinya mengatur pesangon bagi pekerja/buruh yang di PHK karena memasuki usia pensiun.

b. Disamping uang pesangon, uang penghargaan masa kerja dan uang penggantian hak, kepada pekerja yang mengalami PHK juga diberikan Jaminan Kehilangan Pekerjaan (JKP).Dalam Undang-Undang Ketenagakerjaan belum ada diatur JKP, namun telah diatur dalam Undang-Undang Cipta Kerja jo. PP No. 37 Tahun 2021 tentang Jaminan Kehilangan Pekerjaan.

\section{Daftar Pustaka}

Aloysius Uwiyono, dkk, (2014), Asas-Asas Hukum Perburuhan, Jakarta, PT Rajagrafindo

Persada.

Amin Widjaja Tunggal, (2006), Outsourcing Konsep dan Kasus, Jakarta, Harvindo.

Andi Hamzah, (2005), Kamus Hukum, Jakarta, Ghalia Indonesia.

Asri Wijayanti, (2009), Hukum Ketenagakerjaan Pasca Reformasi, Surabaya, Sinar Grafika.

Bahder Johan Nasution, (2008), Metode Penelitian Ilmu Hukum, Jambi, Mandar Maju.

Departemen Pendidikan dan Kebudayaan, (1990) Kamus Besar Bahasa Indonesia, Jakarta, Balai Pustaka.

Ediwarman, (2006), Outsourcing \& Perjanjian Kerja, Jakarta, Dss Publishing. 
Jurnal Magister Hukum Program Pascasarjana Universitas HKBP Nommensen

Volume o2 Nomor o1 Januari 2021 Halaman. 55-79 e-ISSN: 2723-164X p-ISSN: 2722-9858

http://ejournal.uhn.ac.id/index.php/opinion

Farida Hasyim, (2009), Hukum Dagang, Lampung, Sinar Grafika.

Hans Kelsen (b), (2006) diterjemahkan oleh Raisul Mutaqien, Teori Hukum Murni, Bandung, Nuansa \& Nusa Media.

Hans Kelsen (a), (2007) sebagaimana diterjemahkan oleh Somardi, General Theory Of Law and State, Teori Umum Hukum dan Negara, Dasar-Dasar Ilmu Hukum Normatif Sebagai Ilmu Hukum Deskriptif Empirik,BEE , Jakarta, Media Indonesia.

Hardijan Rusli, (2003), Hukum Ketenagakerjaan 2003, Jakarta, Ghalia Indonesia.

HR. Ridwan, (2006), Hukum Administrasi Negara, Jakarta, Raja Grafindo Persada.

Iftida Yasar, (2013), Apakah Benar Outsourcing Bisa Dihapus?, Jakarta, Pohon Cahaya.

Imam Soepomo, (1968). Hukum Perburuhan Bagian Pertama Hubungan Kerja, Jakarta, PPAKRI Bhayangkara.

I Nyoman Putu Budiartha, (2016). Hukum Outsourcing, Malang, Setara Press.

Komang Priambada dan Agus Eka Maharta, (2008). Otsourcing Versus Serikat Pekerja?, Alihdaya, Jakarta, Publishing.

Lalu Husni, (2014). Pengantar Hukum Ketenagakerjaan, Mataram, PT RajaGrafindo Persada.

M. Hisman, ed., (1996). Penelitian Ilmu-Ilmu Sosial, Jilid. I, Jakarta, Fakultas Ekonomi Universitas Indonesia.

M. Solly Lubis, (1994). Filsafat llmu Dan Penelitian, Bandung, Mandar Madju.

Muhamad Sadi Is dan Sobandi, (2020) Hukum Ketenagakerjaan di Indonesia, Jakarta, Kencana.

Richardus Eko Indrajit dan Richardus Djokopranoto, (2011). Proses Outsourcing, Jakarta, PT. Gramedia Widiasarana Indonesia.

Satjipto Rahardjo, (200o) Ilmu Hukum, Bandung, PT. Citra Aditya Bakti.

Sendjun H. Manulang, (1987). Pokok-Pokok Hukum Ketenagakerjaan Indonesia, Jakarta, Erineka Cipta.

Subekti, (1977). Aneka Perjanji, Bandung, Alumni, Cetakan Ke II.

Titik Triwulan dan Shinta Febrian, (2010). Perlindungan Hukum bagi Pasien, Jakarta, Prestasi Pustaka.

Vusyra Azheri, (2011). CorporateSocial Responsibility dari Voluntary menjadi Mandotary, Jakarta, Raja Grafindo Pers.

Astrini Dwi Wahyuni, Penyelesaian Pemutusan Hubungan Kerja (PHK) Terhadap Pekerja Yang Dialihdayakan Studi Kasus : PT Bank Negara Indonesia (Persero)Tbk, Tesis, Fakultas Hukum Indonesia, 2009.

Khairani, "Kedudukan Outsourcing Pasca Putusan Mahkamah Konstitusi Nomor 27/PUUIX/2011", Jurnal Konstitusi, Volume 11, Nomor 4, Desember 2014.

WilmaSilalahi, "Perlindungan Hak Konstitusional Buruh", Jurnal Legalita Volume o1, Nomor o1 Agustus-Desember 2019.

\section{Internet}

https://www.cnbcindonesia.com/market/20200625141748-19-167988/abadi-2o-ribu-pekerjaalih-daya-terkena-phk-akibat-pandemi, diakses tanggal 28 Januari 2021.

http://repository.ump.ac.id/5815/4/PANDU\%2oYUNADI\%20\%3D\%20\%2oBAB\%2oIII.pdf, diakses tanggal 28 Januari 2021.

https://www.saplaw.top/pendekatan-perundang-undangan-statute-approach-dalampenelitian-hukum/, diakses tanggal 29 Januari 2021.

http://repository.unissula.ac.id/12061/2/babI.pdf, diakses tanggal 20 Februari 2021. https://lama.elsam.or.id/downloads/1322798965_HAK_KONSTITUSIONAL_DALAMUUD_194 5.pdf, diakses tanggal 23 February 2021. 
Nommensen Journal of Legal Opinion (NJLO)

Jurnal Magister Hukum Program Pascasarjana Universitas HKBP Nommensen

Volume 02 Nomor o1 Januari 2021 Halaman. 55-79 e-ISSN: 2723-164X p-ISSN: 2722-9858

http://ejournal.uhn.ac.id/index.php/opinion

https://www.apindodiy.or.id/hanya-5-jenis-pekerjaan-yang-boleh-outsourcing/, diakses pada tanggal 15 Maret 2021.

KUH Dagang tidak memuat penafsiran otentik mengenai arti perusahaan,

artonang.blogspot.com/2015/12/pengertian-perusahaan.html?=1, diakses pada tanggal 16 Maret 2021.

https://id-check.net/sinergi-integra-services/499594.html. Diakses pada tanggal 22 April 2021. https://gajimu.com/pekerjaan-yanglayak/jaminan-sosial/BPJS/Jaminan-kehilangan-pekerjaanjkp. Diakses pada 16 Maret 2021. 